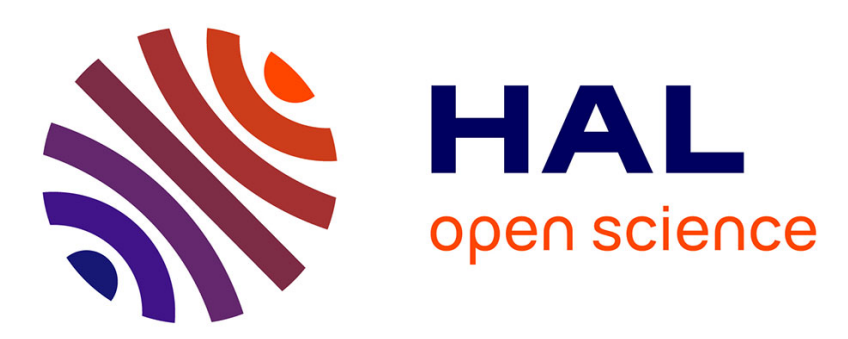

\title{
Solubility and solution enthalpy of a cesium-selective calixarene in supercritical carbon dioxide
}

\author{
Adrien Dartiguelongue, Antoine Leybros, Agnès Grandjean
}

\section{To cite this version:}

Adrien Dartiguelongue, Antoine Leybros, Agnès Grandjean. Solubility and solution enthalpy of a cesium-selective calixarene in supercritical carbon dioxide. Journal of Supercritical Fluids, 2017, 125, pp.42-49. 10.1016/j.supflu.2017.01.017 . cea-02380589

\section{HAL Id: cea-02380589 https://hal-cea.archives-ouvertes.fr/cea-02380589}

Submitted on 9 Dec 2019

HAL is a multi-disciplinary open access archive for the deposit and dissemination of scientific research documents, whether they are published or not. The documents may come from teaching and research institutions in France or abroad, or from public or private research centers.
L'archive ouverte pluridisciplinaire HAL, est destinée au dépôt et à la diffusion de documents scientifiques de niveau recherche, publiés ou non, émanant des établissements d'enseignement et de recherche français ou étrangers, des laboratoires publics ou privés. 


\title{
Solubility and solution enthalpy of a cesium-selective calixarene in
}

\section{supercritical carbon dioxide}

\author{
Adrien Dartiguelongue, Antoine Leybros* and Agnès Grandjean \\ CEA, DEN, DTCD, SPDE, Laboratoire des Procédés Supercritiques et de Décontamination, \\ B.P. 17171, 30207 Bagnols-sur-Cèze, France \\ * antoine.leybros@cea.fr, +33466791641
}

\begin{abstract}
This paper investigates the solubility of the cesium-selective extractant $25,27-$ Bis(1-octyloxy)calix[4]arene-crown-6, 1,3-alternate (CalixOctyl) in supercritical $\mathrm{CO}_{2}$ (SC$\mathrm{CO}_{2}$ ). A dynamic set-up with a solvent loop was used, avoiding any plugging of the solute and allowing precise quantification by UV/visible spectrophotometry. The solubility measurements were carried out between 10.3 and $27.4 \mathrm{MPa}$ at 314,324 and $334 \mathrm{~K}$. The solubility of CalixOctyl in $\mathrm{SC}-\mathrm{CO}_{2}$ ranged from $(0.20 \pm 0.02) \cdot 10^{-6} \mathrm{~mol} \cdot \mathrm{mol}^{-1}$ at $334 \mathrm{~K}$ and 10.4 MPa to $(72.78 \pm 0.31) \cdot 10^{-6} \mathrm{~mol} \cdot \mathrm{mol}^{-1}$ at $324 \mathrm{~K}$ and $27.4 \mathrm{MPa}$, approximately 100 times higher than that of simple $p$-t-butylcalix[4,6,8]arenes and calix[4]arene. The solution enthalpy of CalixOctyl in $\mathrm{SC}-\mathrm{CO}_{2}$ was also studied. The heat flow during solubilization at $24.0 \mathrm{MPa}$ and 314,324 and $334 \mathrm{~K}$ was measured by differential scanning calorimetry. The temperature dependence of the solution enthalpy and its extrapolation to any pressure are discussed.
\end{abstract}

Keywords: CalixOctyl, supercritical $\mathrm{CO}_{2}$, solubility, solution enthalpy, cesium extraction 


\section{Introduction}

Calixarenes can be defined as cyclic oligomers produced by the base or acid-induced condensation of a phenol with an aldehyde. This reaction was carried out for the first time in 1872 by Baeyer [1], who obtained a cement-like substance by mixing miscellaneous phenols and aldehydes. Over the following century, studies of this kind of reaction continued for the synthesis of resinous then crystalline materials for applications in the petroleum and pharmaceutical industry. Following the first synthesis of calixarenes by Gutsche [2], these compounds were used as enzyme mimics in the early 1970s. Gutsche's project was to design specific receptors for a given molecular substrate and functionalize these receptors with chemical groups able to interact with the substrate. Subsequent advances in calixarene chemistry now allow the synthesis of many functionalized compounds with highly selective yields. Calixarenes can be used to prevent the oxidation of organic polymers [3] and functionalized compounds have been employed as phase-transfer agents for reactions in nonpolar media [4], as ion scavengers in resins for the encapsulation of electronic devices [5], as accelerators for instant adhesives [6], as films for chemical sensing applications $[7,8]$ and as catalysts for hydrolysis [9] or polymerization reactions [10].

As mentioned in several reviews however [11-15], the main application of calixarenes is the chelation of metallic cations and neutral species. Calixarenes have notably been used to extract the following species from aqueous solutions: $\alpha$-amines and $\alpha$-amino acid methylesters [16], gold [17], copper [18], technetium [19], americium and europium [20], uranium [21], alkaline earth metals [22] and alkali metal cations [23]. Cesium extraction is of particular interest because of the huge volumes of ${ }^{137}$ Cs-polluted waste awaiting decontamination. Calix[4]arenes-crown-6 [24, 25] (consisting of four phenol units functionalized by a crown ether with six oxygen atoms on the lower rim) are the most efficient and cesium-selective of these compounds. They have been used extensively for the liquid-liquid extraction of cesium 
in both acid and basic media [26-33]. In particular, 25,27-Bis(1-octyloxy)calix[4]arenecrown-6, 1,3-alternate (CalixOctyl, CAS $\mathrm{n}^{\circ}$ 161282-97-9) diluted in 1,2-nitrophenyl hexyl ether allowed a complete recovery of cesium from nitric acid solutions with a very high selectivity over sodium [24].

The high diffusivity and solvent power of supercritical $\mathrm{CO}_{2}\left(\mathrm{SC}-\mathrm{CO}_{2}\right)$ make it a promising candidate for the depollution of Cs-contaminated soils [34]. An additional benefit of this approach is that it allows to minimize harmful and flammable solvents or strong oxidants quantities. Thereby, Kanekar et al. [35] combined calix[4]arenes-crown-6 (or crown ethers) and organic modifiers to recover cesium from soils in $\mathrm{SC}-\mathrm{CO}_{2}$. Based on environmental, economic and safety considerations however, the solubility of a selective extractant alone or with an appropriate modifier is one of the key parameter of such a process. Very little is known though about the solubility of calixarenes in $\mathrm{SC}-\mathrm{CO}_{2}$. Graham et al. [36] found that simple $p$-t-butylcalix[4,6,8]arenes were only weakly soluble in $\mathrm{SC}-\mathrm{CO}_{2}$ (at best $1.03 \cdot 10^{-6} \mathrm{~mol} \cdot \mathrm{mol}^{-1}$ at $20.6 \mathrm{MPa}$ and $323.1 \mathrm{~K}$ ). The lack of data available on the use of calixarenes to extract cesium lead us to investigate solubility in $\mathrm{SC}-\mathrm{CO}_{2}$ of CalixOctyl, the calix[4]arene-crown-6 that previous studies suggest is the most efficient and selective for cesium extraction $[24,35]$. This paper reports solubility measurements performed at $10.3-$ $27.4 \mathrm{MPa}$ at 314,324 and $334 \mathrm{~K}$. In order to better our understanding of the solubilization process, we also measured the solution enthalpy of CalixOctyl — a quantity rarely determined experimentally_at the same three temperatures and at a fixed pressure of $24.0 \mathrm{MPa}$. 


\section{Materials and methods}

\subsection{Chemicals}

CalixOctyl chemical structure is shown in Fig. 1. It was synthesized following the original scheme of Casnati et al. [25] and its purity (> 95\%) was verified by measuring its melting point by ${ }^{1} \mathrm{H}$ and ${ }^{13} \mathrm{C}$ NMR, IR spectroscopy and size-exclusion chromatography.

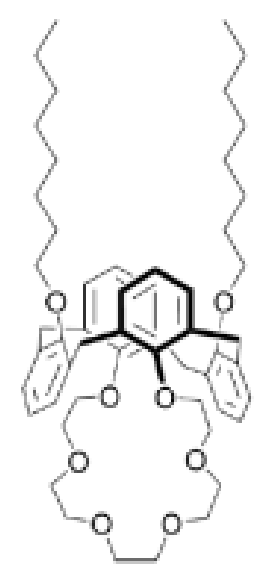

Fig. 1. Chemical structure of CalixOctyl (25,27-Bis(1-octyloxy)calix[4]arene-crown-6, 1,3-alternate).

The remaining chemicals and the $\mathrm{CO}_{2}$ (Air Liquide, $\geq 99.99 \%$ ) were used without further purification: dibenzo-24-crown-8 (Aldrich, 98\%, CAS n¹4174-09-5), ethyl acetate (Fluka, LC-MS Chromasolv $^{\circledR}, \geq 99.7 \%$ ) and acetonitrile (Fluka, LC-MS UltraChromasolv ${ }^{\circledR}, \geq$ 99.9\%) were respectively used to validate the experimental device, for the extraction of CalixOctyl from $\mathrm{SC}-\mathrm{CO}_{2}$, and for UV analysis. The DSC sensor was calibrated in temperature and enthalpy using indium standard (Sigma-Aldrich) and benzoic acid (Merck Millipore, Emsure ${ }^{\circledR}$ Reag. Ph. Eur., $\geq 99.9 \%$,).

\subsection{Solubility measurements}

A dynamic method was developed, involving the solubilization of CalixOctyl in flowing $\mathrm{SC}-\mathrm{CO}_{2}$ and the continued recovery of the solute from the $\mathrm{CO}_{2}$ using ethyl acetate. This approach is similar to the one used by Cross et al. [37] to measure the solubility of solid 
compounds in $\mathrm{SC}-\mathrm{CO}_{2}$. A diagram of the experimental setup is shown in Fig. 2 and the global procedure to acquire solubility data is detailed hereafter.

A high pressure pump (PU-2080- $\mathrm{CO}_{2}$ Plus, Jasco, uncertainty on the $\mathrm{CO}_{2}$ flow rate: \pm $3.3 \cdot 10^{-5} \mathrm{~cm}^{3} \cdot \mathrm{s}^{-1}$ ) was used to deliver $\mathrm{CO}_{2}$ at up to $1.7 \cdot 10^{-1} \mathrm{~cm}^{3} \cdot \mathrm{s}^{-1}$ at $263 \mathrm{~K}$. The device was heated using a heat exchanger (labeled HE in Fig. 2) attached to a stove ( $\mathrm{S}$ in Fig. 2, FED 115, Binder) enclosing the whole device. An HPLC switching valve (SWV, model 7000, Rheodyne) enabled the $\mathrm{CO}_{2}$ flow to be directed at either the reactor or the back-pressure regulator. The titanium solubilization reactor $\left(\mathrm{R}, 38 \mathrm{~cm}^{3}\right.$, Top Industrie) was capped with two $20 \mu \mathrm{m}$ sintered stainless steel disks to prevent mechanical entrainment of the undissolved solute. The reactor was loaded with glass beads $(0.75-1.00 \mathrm{~mm}$ in diameter) in which CalixOctyl was dispersed. Supercritical $\mathrm{CO}_{2}$ saturated with CalixOctyl was then brought into contact with an ethyl acetate flow delivered by a solvent pump (PS, PU-4180, Jasco, standard uncertainty on the ethyl acetate flow rate: $\left.\pm 3.3 \cdot 10^{-5} \mathrm{~cm}^{3} \cdot \mathrm{s}^{-1}\right)$. Ethyl acetate does not react with SC- $\mathrm{CO}_{2}$ and the two compounds are fully miscible [38], allowing the formation of a mixed flow. In the other hand, ethyl acetate totally solubilizes CalixOctyl in these conditions. A back-pressure regulator (BPR, Tescom, 26-1700 series) was used to control the operating pressure in the device. Downstream of the BPR, $\mathrm{CO}_{2}$ and ethyl acetate were separated by adjusting the solvent power. The ethyl acetate containing CalixOctyl was gathered in collectors $\mathrm{C} 1$ and $\mathrm{C} 2$. The total mass of $\mathrm{CO}_{2}$ flowing through the device $\left(m \mathrm{CO}_{2}\right)$ was measured using a thermal mass flow meter (FM, SLA5860, Brooks, standard uncertainty on the $\mathrm{CO}_{2}$ mass flow: $\left.\pm 1.7 \cdot 10^{-7} \mathrm{~kg} \cdot \mathrm{s}^{-1}\right)$. 


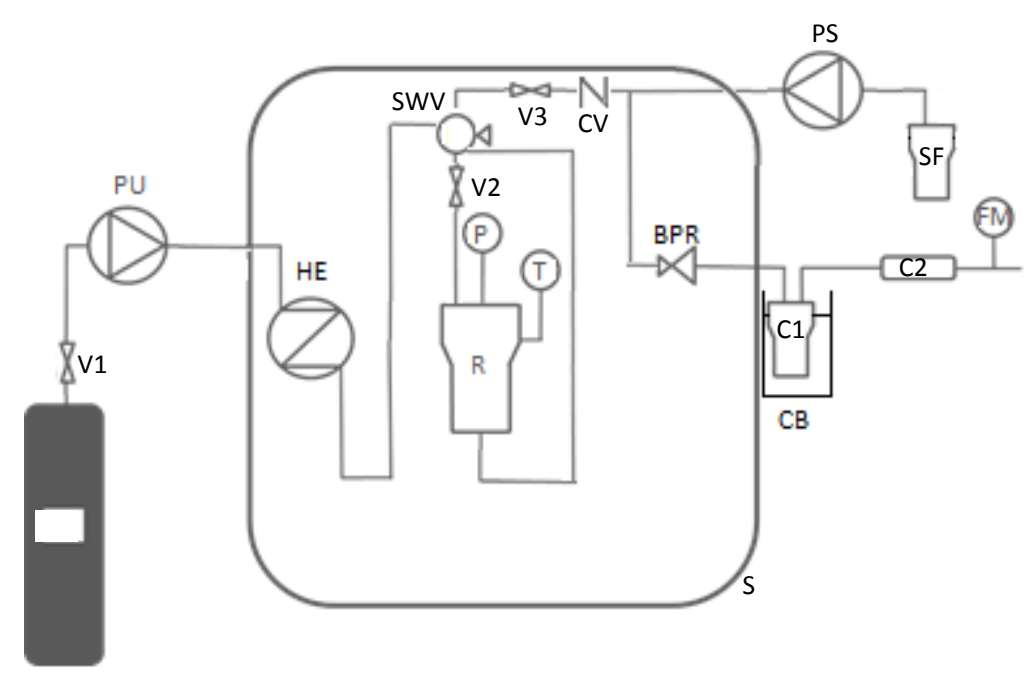

Fig. 2. Diagram of the experimental setup used to measure the solubility of CalixOctyl (25,27-Bis(1octyloxy)calix[4]arene-crown-6, 1,3-alternate) in supercritical $\mathrm{CO}_{2}$. V1, V2 and V3: stop valves; PU: $\mathrm{CO}_{2}$ pump; HE: heat exchanger; R: solubilization reactor; SWV: switching valve; CV: check valve; SF: solvent flask; PS: solvent pump; BPR: back-pressure regulator; S: stove; C1: glass collector; CB: cooling bath; C2: steel collector; FM: mass flow meter.

The operating temperature and pressure were measured in the solubilization reactor using a pressure transmitter (PA-33X, Keller, relative uncertainty: $0.1 \%$ ) and a $\mathrm{K}$ type thermocouple (HMPV-KI-M, USA, relative uncertainty: 0.75\%). All masses were determined with a precision balance (DV214C, Ohaus, standard uncertainty: $\pm 10^{-7} \mathrm{~kg}$ ).

The solubility measurements were conducted as follows:

- The reactor $\mathrm{R}$ was loaded with a known mass $\left(m_{0}\right)$ of CalixOctyl.

- The reactor $\mathrm{R}$ was by-passed using the switching valve and the device was heated and pumped up to operating conditions.

- The $\mathrm{CO}_{2}$ flow rate, $F_{\mathrm{CO}_{2}}$, was kept fixed at $1.7 \cdot 10^{-2} \mathrm{~cm}^{3} \cdot \mathrm{s}^{-1}$ and ethyl acetate was injected into the device at $F_{E t O A C}=3.3 \cdot 10^{-2} \mathrm{~cm}^{3} \cdot \mathrm{s}^{-1}$.

- After a short equilibration time, the injection of ethyl acetate was stopped and the valve was switched back. 
- The operating pressure was readjusted.

- Ethyl acetate was injected once more with a flow rate, $F_{E t O A C}=3.3 \cdot 10^{-2} \mathrm{~cm}^{3} \cdot \mathrm{s}^{-1}$.

- Equilibrium was maintained for 1 hour in the solubilization reactor. The pump was then stopped, the $\mathrm{CO}_{2}$ inlet valve $\mathrm{V} 1$ was closed, and the contents of the collectors $\mathrm{C} 1$ and $\mathrm{C} 2$ and the reactor $\mathrm{R}$ were weighed. In the equations below, the mass of solution in $\mathrm{C} 1$ is denoted $m_{l}$ and the mass of CalixOctyl remaining in $\mathrm{R}, m_{2}$. No trace of ethyl acetate was found in $\mathrm{C} 2$.

\subsection{Quantitative analysis}

The quantitative analysis of CalixOctyl was performed by UV/visible spectrophotometry (UV-1800, Shimadzu) at $268 \mathrm{~nm}$ (an absorbance maximum), with quartz UV cells (10 mm path length, Hellma Analytics). Because ethyl acetate also absorbs at 268 $\mathrm{nm}$, it was completely removed from the collected solution, first using a rotary evaporator and then a vacuum gas manifold. The solid residue was then dissolved in an appropriate volume of acetonitrile, $V_{M e C N}$, and the absorbance of this new solution was determined. The following relationship was obtained by regression analysis $\left(R^{2}=0.997\right)$ between the absorbance at 268 $\mathrm{nm}, A_{268 \mathrm{~nm}}$, and the molar concentration of CalixOctyl in acetonitrile, $C_{\text {Calixoctyl }}$ (in $\left.\mathrm{mol} \cdot \mathrm{L}^{-1}\right)$

$A_{268 \mathrm{~nm}}=1788.6 \times C_{\text {Calixoctyl }}$

The main advantage of this set-up is that it avoids solute plugging [37]. Indeed, CalixOctyl is highly soluble in ethyl acetate $\left(>1.2 \cdot 10^{-2} \mathrm{~mol} \cdot \mathrm{L}^{-1}\right)$ at $298.2 \mathrm{~K}$ according to preliminary tests) and therefore remains dissolved in the liquid solvent downstream of the back-pressure regulator (where $\mathrm{CO}_{2}$ is gaseous). This avoids any clogging of the instrument. Moreover, CalixOctyl is more precisely quantified in solution than by simple weighing, 
especially for small amounts of solute, using UV/visible spectrophotometry or another analytical technique (e.g. refractometry or mass spectrometry).

\subsection{Solubility calculations, uncertainties and mass balances}

The solubility of CalixOctyl (mol· $\mathrm{mol}^{-1}$ ) was calculated using Eq. (2):

$y=\frac{n_{\text {Calixoctyl }}}{n_{\text {CalixOctyl }}+n_{\mathrm{CO}_{2}}}=\frac{C_{\text {Calixoctyl }} \times V_{\mathrm{MeCN}}}{C_{\text {CalixOctyl }} \times V_{M e C N}+\frac{m_{\mathrm{CO}_{2}}}{M_{\mathrm{CO}_{2}}}}$

where $C_{\text {Calixoctyl }}$ is the molar concentration $\left(\mathrm{mol} \cdot \mathrm{L}^{-1}\right)$ in CalixOctyl determined by UV/visible spectrophotometry analysis using Eq. (1), $V_{M e C N}$ is the volume of acetonitrile (L), $M_{\mathrm{CO} 2}$ is the molar mass of $\mathrm{CO}_{2}$, and $\rho_{\mathrm{CO}_{2}}$ is the density of $\mathrm{CO}_{2}\left(\mathrm{~kg} \cdot \mathrm{m}^{-3}\right)$ at the experimental pressure and temperature, obtained from the NIST database [39]. Each experimental point was triplicated and the standard uncertainties for the solubility values were calculated. The standard uncertainties for the pressure and temperature during an experiment were estimated to be $1.3 \mathrm{~K}$ and $0.08 \mathrm{MPa}$, respectively.

The mass balances of CalixOctyl, $\mathrm{CO}_{2}$ and ethyl acetate were also calculated to evaluate the reliability of the experimental data. The mean percentage deviations of the mass balances for each triplicated point were calculated using Eqs. (3-5):

$\overline{\Delta \mathrm{m}_{\mathrm{PFPeA}}}=\frac{100}{2} \cdot \sum_{\mathrm{i}=1}^{2}\left(\frac{\left|\mathrm{m}_{0}-\left(\mathrm{m}_{1}+\mathrm{m}_{2}+\mathrm{m}_{3}+\mathrm{m}_{4}\right)\right|}{\mathrm{m}_{0}}\right)_{\mathrm{i}}$

$\overline{\Delta \mathrm{m}_{\mathrm{CO}_{2}}}=\frac{100}{2} \cdot \sum_{\mathrm{i}=1}^{2}\left(\frac{\left|\mathrm{m}_{\mathrm{CO}_{2}}-\mathrm{m}_{\mathrm{CO}_{2} \text { pumped }}\right|}{\mathrm{m}_{\mathrm{CO}_{2}}}\right)_{\mathrm{i}}$

$\overline{\Delta \mathrm{m}_{\mathrm{CO}_{2}}}=\frac{100}{2} \cdot \sum_{\mathrm{i}=1}^{2}\left(\frac{\left|\mathrm{m}_{\mathrm{CO}_{2}}-\mathrm{m}_{\mathrm{CO}_{2} \text { pumped }}\right|}{\mathrm{m}_{\mathrm{CO}_{2}}}\right)_{\mathrm{i}}$ 
where $m_{\mathrm{CO}_{2} \text { pumped }}$ and $m_{\text {AcOEtpumped }}$ are the total masses of $\mathrm{CO}_{2}$ and ethyl acetate delivered during the entire experiment, calculated using Eqs. (6) and (7):

$m_{\mathrm{CO}_{2} \text { pumped }}=\mathrm{F}_{\mathrm{CO}_{2}} \times t_{\text {exp }} \times \rho_{\mathrm{CO}_{2} \text { pumped }}$

$m_{\text {AcOEtpumped }}=F_{\text {AcOEt }} \times t_{\text {exp }} \times \rho_{\text {AcOEt }}$

Here, $t_{\text {exp }}$ is the duration of the experiment (in seconds), $\rho_{\mathrm{CO}_{2} \text { pumped }}$ the density of injected $\mathrm{CO}_{2}$ (in $\mathrm{kg} \cdot \mathrm{cm}^{-3}$, at $263 \mathrm{~K}$ ) and $\rho_{\text {AcOEt }}$, the density of ethyl acetate.

\subsection{Solution enthalpy measurements}

The experimental setup (Fig. 3, Setaram Instrumentation) based on differential scanning calorimetry (DSC) used to measure solution enthalpies in $\mathrm{SC}-\mathrm{CO}_{2}$ is similar to the one described by Stassi and Schiraldi [40]. Experiments were performed at constant temperature and pressure and variable $\mathrm{CO}_{2}$ flow rate.

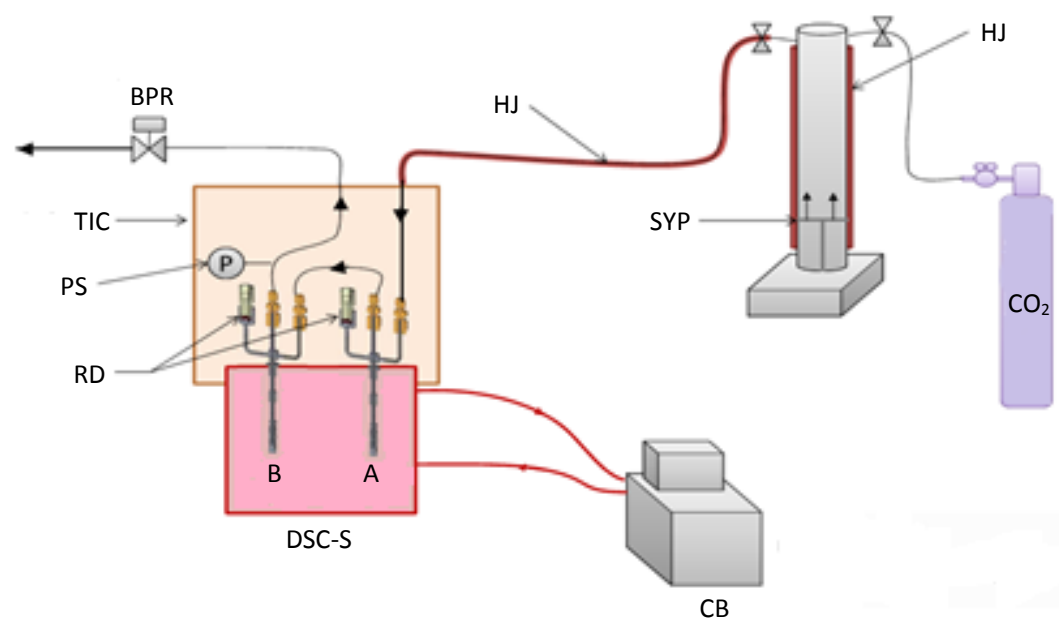

Fig. 3. Diagram of the device used to measure solution enthalpies. SYP: syringe pump, HJ: heating jacket, DSCS: DSC sensor, CB: cooling bath, A: reference cell, B: measurement cell, RD: rupture disks, PS: pressure sensor, TIC: thermally insulated chamber, BPR: back-pressure regulator.

A syringe pump (SYP, Teledyne 260D, Isco, relative uncertainty on the $\mathrm{CO}_{2}$ flow rate: $0.5 \%$ ) was used to deliver $\mathrm{CO}_{2}$ at up to $1.8 \mathrm{~cm}^{3} \cdot \mathrm{s}^{-1}$. The temperature in the pump and in the $\mathrm{CO}_{2}$ line 
was adjusted using heating jackets $(\mathrm{HJ})$ and a temperature controller (model M3, Ascon France, relative uncertainty on temperature measurements: $0.25 \%$ ). $\mathrm{SC}-\mathrm{CO}_{2}$ was conveyed into the Inconel reference (A) and measurement (B) cells (150 $\mu \mathrm{L}$, Autoclave France), which were both enclosed in the DSC sensor (DSC-S, Sensys evo DSC, Setaram Instrumentation, temperature accuracy/precision: 0.1/0.02 K, heat flow accuracy/precision: 1/0.1\%). All the tubes allowing the circulation of $\mathrm{CO}_{2}$ from $\mathrm{A}$ to $\mathrm{B}$ had rigorous thermal insulation to avoid any temperature difference between the two cells. The operating pressure was controlled via a back-pressure regulator (BPR, Tescom, 26-1700 series) and measured via a pressure sensor (model XPC10, Measurement Specialties, relative uncertainty: 0.25\%). The experimental data were visualized using Calisto ${ }^{\circledR}$ (v. 1.38).

The calorimetric analysis involved the following steps:

- Cell B was filled with the solid sample to be analyzed.

- The device was heated up to the operating temperature.

- The device was pumped up to the operating pressure, which was then maintained using the BPR. The $\mathrm{CO}_{2}$ flow rate was set to $1.7 \cdot 10^{-2} \mathrm{~cm}^{3} \cdot \mathrm{s}^{-1}$.

- Once the DSC signal (heat flow) had stabilized, the $\mathrm{CO}_{2}$ flow rate was lowered in a stepwise fashion, with a different plateau for the signal at each flow rate.

Solution enthalpy experiments were carried out at 314, 324 and $334 \mathrm{~K}$, under 1.7, 1.5, 1.3 and $1.1 \cdot 10^{-2} \mathrm{~cm}^{3} \cdot \mathrm{s}^{-1} \mathrm{CO}_{2}$ at a fixed pressure of $24.0 \mathrm{MPa}$. The DSC signal stabilizes rapidly at these flow rates. Fig. 4 presents a typical DSC profile obtained in this way. 
Time (s)

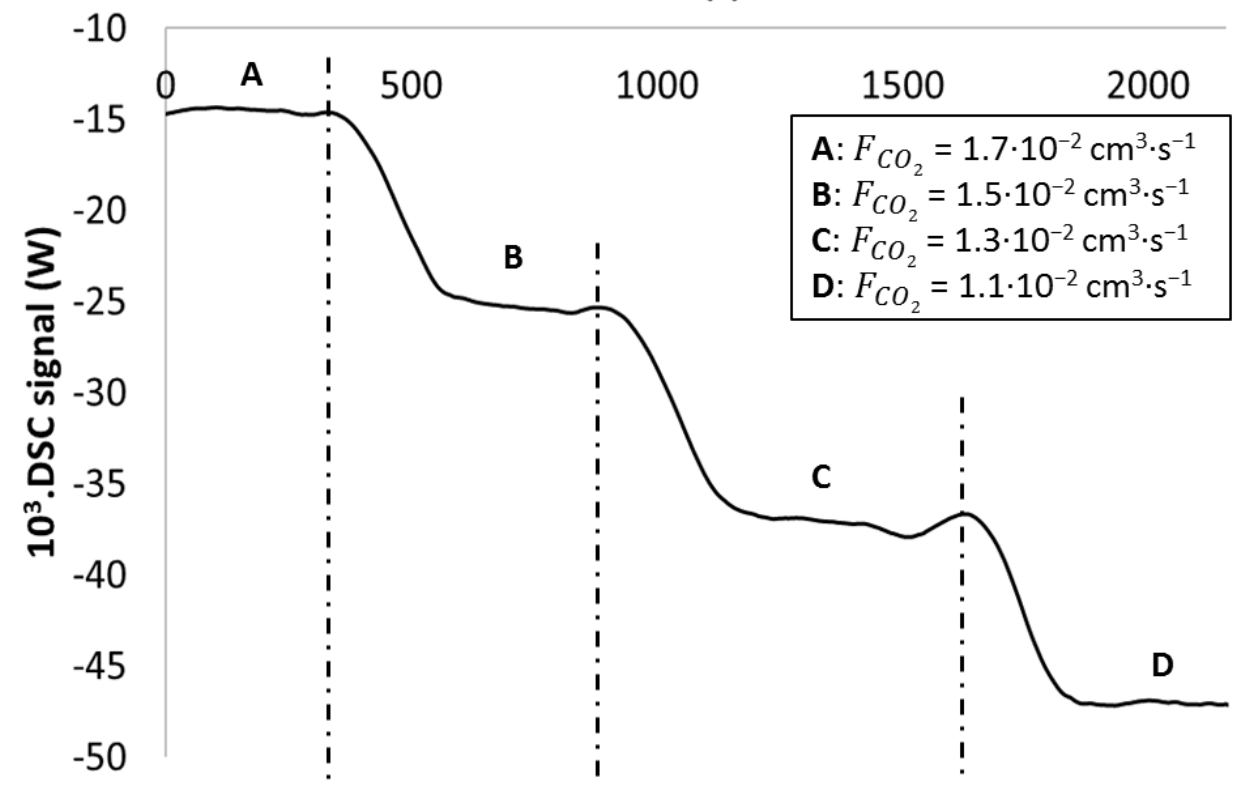

Fig. 4. Differential scanning calorimetry signal measured for CalixOctyl (25,27-Bis(1-octyloxy)calix[4]arenecrown-6, 1,3-alternate) at $\mathrm{CO}_{2}$ flow rates of $1.7,1.5,1.3$ and $1.1 \cdot 10^{-2} \mathrm{~cm}^{3} \cdot \mathrm{s}^{-1}$ at $314 \mathrm{~K}$ and $24.0 \mathrm{MPa}$.

To correct for the effects of asymmetry in the system (i.e. intrinsic differences between cells $\mathrm{A}$ and $\mathrm{B}$ ), the values obtained for $\mathrm{CO}_{2}$ alone under the same operating conditions (cell $\mathrm{B}$ remaining empty) were subtracted from the raw signal. Thus, one characteristic plateau value of the DSC signal ( $s$ in W) was collected for each $\mathrm{CO}_{2}$ flow rate tested at each temperature and pressure. Each measurement was triplicated in order to calculate the standard uncertainty associated with each value. The standard uncertainties for the pressure and temperature were estimated to be $0.02 \mathrm{~K}$ and $0.08 \mathrm{MPa}$, respectively.

Eq. 8 was used to relate the DSC signal at constant pressure to the solution enthalpy. According to Riva and Schiraldi [41] indeed, the observed signal depends on the solubility of CalixOctyl in $\mathrm{CO}_{2}\left(y, \mathrm{~mol} \cdot \mathrm{mol}^{-1}\right)$, the $\mathrm{CO}_{2}$ flow rate $\left(F_{\mathrm{CO}_{2}}, \mathrm{~g} \cdot \mathrm{s}^{-1}\right.$, converted from $\mathrm{cm}^{3} \cdot \mathrm{s}^{-1}$ using the $\mathrm{CO}_{2}$ densities in the NIST database [39]), the molar mass of $\mathrm{CO}_{2}\left(M_{C O 2}, \mathrm{~g} \cdot \mathrm{mol}^{-1}\right)$, and the molar solution enthalpy of CalixOctyl in $\mathrm{CO}_{2}\left(\Delta H_{s o l}, \mathrm{~J} \cdot \mathrm{mol}^{-1}\right)$ as follows: 
$s=-y \times \Delta H_{\text {Sol }} \times \frac{F_{\mathrm{CO}_{2}}}{M_{\mathrm{CO} 2}}$

\section{Results and discussion}

\subsection{Device validation}

The reliability of the device used for solubility measurements (Fig. 2) was assessed by comparing the values obtained for dibenzo-24-crown-8 (DB24C8) in $\mathrm{SC}^{-\mathrm{CO}_{2}}$ with those published by Shamispur et al. [42]. The following regression equation $\left(R^{2}=0.991\right)$ was obtained between the absorbance at the $275.4 \mathrm{~nm}$ maximum, $A_{275.4 \mathrm{~nm}}$, and the molar concentration of dibenzo-24-crown-8 in acetonitrile, $C_{D B 24 C 8}\left(\mathrm{in} \mathrm{mol} \cdot \mathrm{L}^{-1}\right)$ :

$A_{275.4 \mathrm{~nm}}=1841.1 \times C_{D B 24 C 8}+0.0706$

Table 1 shows the solubilities measured at 16.2,20.3 and 24.3 MPa with the temperature kept fixed at $318 \mathrm{~K}$ (using Eq. 2), along with the corresponding mean deviations of the mass balances (Eqs. (3-5)).

\section{Table 1}

Solubility of dibenzo-24-crown-8 in supercritical $\mathrm{CO}_{2}$ as measured in this study and as reported by Shamispur et al. [42].

\begin{tabular}{ccccccc} 
Pressure & Temperature & $10^{6} \cdot y$ (this work) & $\overline{\Delta m_{D B 24 C 8}}$ & $\overline{\Delta m_{C O_{2}}}$ & $\overline{\Delta m_{A c O E t}}$ & $10^{6} \cdot y[42]$ \\
$(\mathrm{MPa})$ & $(\mathrm{K})$ & $\left(\mathrm{mol} \cdot \mathrm{mol}^{-1}\right)$ & $(\%)$ & $(\%)$ & $(\%)$ & $\left(\mathrm{mol} \cdot \mathrm{mol}^{-1}\right)$ \\
\hline 16.2 & 318 & $16.2 \pm 0.1$ & 4.5 & 9.9 & 6.2 & 15.8 \\
\hline 20.3 & 318 & $24.1 \pm 0.2$ & 8.9 & 3.5 & 7.3 & 22.4 \\
\hline 24.3 & 318 & $38.2 \pm 0.1$ & 7.1 & 9.3 & 7.6 & 33.4
\end{tabular}


The two datasets are in good agreement. As expected, the solubility of dibenzo-24-crown-8 increases with the pressure at constant temperature. These results show that our experimental device is a reliable means to measure the solubility of solid compounds in $\mathrm{SC}-\mathrm{CO}_{2}$.

\subsection{Solubility of CalixOctyl in $\mathrm{SC}-\mathrm{CO}_{2}$}

The solubility of CalixOctyl was determined in terms of equilibrium mole fraction of solute in $\mathrm{SC}-\mathrm{CO}_{2}$ at 314,324 and $334 \mathrm{~K}$ for pressures ranging from 10.3 to $27.4 \mathrm{MPa}$, as summarized in Table 2.

\section{Table 2}

Solubility of CalixOctyl (25,27-Bis(1-octyloxy)calix[4]arene-crown-6, 1,3-alternate) in supercritical $\mathrm{CO}_{2}$.

\begin{tabular}{|c|c|c|c|c|c|c|}
\hline $\begin{array}{c}\text { Temperature } \\
\text { (K) }\end{array}$ & $\begin{array}{l}\text { Pressure } \\
(\mathrm{MPa})\end{array}$ & $\begin{array}{c}\rho_{\mathrm{CO}_{2}} \\
\left(\mathrm{~kg} \cdot \mathrm{m}^{3}\right)\end{array}$ & $\begin{array}{c}10^{6} \cdot y \\
\left(\mathrm{~mol} \cdot \mathrm{mol}^{-1}\right)\end{array}$ & $\begin{array}{c}\overline{\Delta m_{\text {Callxoctyl }}} \\
(\%)\end{array}$ & $\begin{array}{c}\overline{\Delta m_{\mathrm{CO}_{2}}} \\
(\%)\end{array}$ & $\begin{array}{c}\overline{\Delta m_{\text {ACOEt }}} \\
(\%)\end{array}$ \\
\hline \multirow{5}{*}{314} & 10.3 & 647.0 & $3.1 \pm 0.2$ & 7.5 & 4.7 & 4.6 \\
\hline & 14.5 & 766.4 & $10.6 \pm 0.1$ & 9.4 & 4.9 & 6.7 \\
\hline & 19.3 & 828.8 & $27.4 \pm 0.1$ & 8.8 & 4.8 & 6.1 \\
\hline & 24.0 & 872.4 & $34.3 \pm 0.1$ & 10.1 & 2.7 & 6.5 \\
\hline & 26.7 & 887.4 & $37.4 \pm 0.2$ & 9.2 & 4.7 & 8.6 \\
\hline \multirow{5}{*}{324} & 10.3 & 417.1 & $0.3 \pm 0.02$ & 5.9 & 10.3 & 7.8 \\
\hline & 15.8 & 712.0 & $9.2 \pm 0.1$ & 4.8 & 2.4 & 8.3 \\
\hline & 21.4 & 795.0 & $31.2 \pm 0.2$ & 9.3 & 7.4 & 8.3 \\
\hline & 24.0 & 825.5 & $52.6 \pm 0.2$ & 7.6 & 1.4 & 4.0 \\
\hline & 27.4 & 848.6 & $72.8 \pm 0.3$ & 7.0 & 6.9 & 4.6 \\
\hline & 10.4 & 308.2 & $0.2 \pm 0.02$ & 10.4 & 5.8 & 10.5 \\
\hline & 15.6 & 617.2 & $4.0 \pm 0.1$ & 7.8 & 7.4 & 9.1 \\
\hline
\end{tabular}



19.9
717.9
$19.8 \pm 0.3$
9.1
1.7
8.3

334

22.8

757.6

$38.5 \pm 0.1$

6.9

2.6

8.1

24.0

772.3

$42.6 \pm 0.2$

8.1

6.8

7.9

25.9

792.9

$46.4 \pm 0.3$

9.1

11.0

9.9

The solubility of CalixOctyl is low, varying from $(0.2 \pm 0.02) \cdot 10^{-6} \mathrm{~mol} \cdot \mathrm{mol}^{-1}$ at $334 \mathrm{~K}$ and $10.4 \mathrm{MPa}$ to $(72.8 \pm 0.3) \cdot 10^{-6} \mathrm{~mol}_{\mathrm{mol}} \mathrm{m}^{-1}$ at $324 \mathrm{~K}$ and $27.4 \mathrm{MPa}$. Fig. 5 shows how the solubility of CalixOctyl evolves as a function of pressure and temperature.

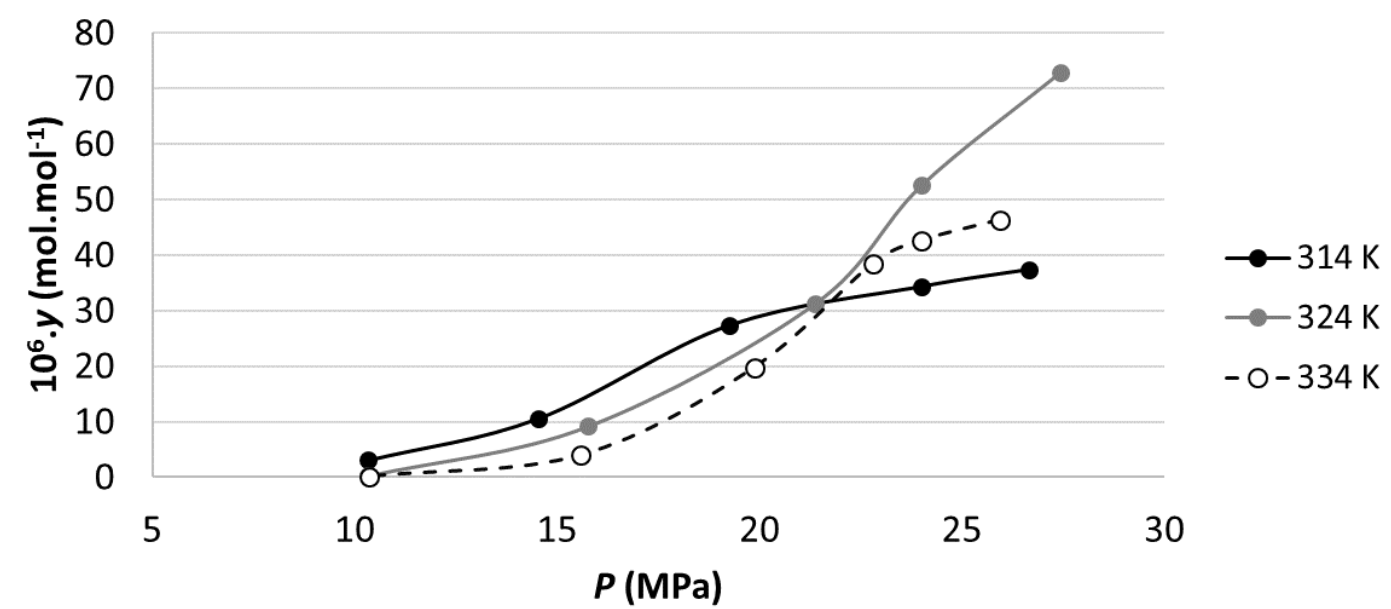

Fig. 5. Solubility of CalixOctyl (25,27-Bis(1-octyloxy)calix[4]arene-crown-6,1,3-alternate) as a function of pressure at 314,324 and $334 \mathrm{~K}$.

The solubility isotherms in Fig. 5 intersect at a pressure of 21.4 MPa. In other words, the solubility is temperature independent at this pressure. At lower pressures, the solubility of CalixOctyl increases with the pressure but decreases as the temperature increases; i.e. the solubility of CalixOctyl increases as the $\mathrm{CO}_{2}$ becomes denser. This is the trend usually observed for liquid and solid solutes in $\mathrm{SC}-\mathrm{CO}_{2}[43]$. Above the crossover pressure however, whereas the solubility still increases with the pressure, the solubility is highest at the 
intermediate temperature $(324 \mathrm{~K})$. This may be because the temperature influences both the $\mathrm{CO}_{2}$ density and the vapor pressure of the solute and its potential interactions with $\mathrm{CO}_{2}$.

The solubilities of $p$-t-butylcalix[4,8]arenes and calix[4]arene in $\mathrm{SC}_{-} \mathrm{CO}_{2}$ are also maximal at a similar intermediate temperature $(323 \mathrm{~K})$ but there is no crossover pressure for either of these compounds [36]. Crossover pressure points are observed for crown ethers however-at around 16.2 MPa for dibenzo-24-crown-8, dibenzo-27-crown-9 and dibenzo-30crown-10 [42]. In qualitative terms, since CalixOctyl combines the structures of a calixarene and of a crown ether, its solubility curves should also reflect the presence of these two components. Quantitatively, CalixOctyl and crown ethers are roughly one hundred times more soluble in $\mathrm{SC}-\mathrm{CO}_{2}$ than are simple calixarenes. This is consistent with the observations of Sarbu et al. [44] and Kilic et al. [45] that the addition of ether chains to a macromolecule can dramatically increase its solubility in $\mathrm{SC}-\mathrm{CO}_{2}$.

\subsection{Solution enthalpy of CalixOctyl in $\mathrm{SC}-\mathrm{CO}_{2}$}

Fig. 6 shows the evolution of the corrected DSC signal as a function of the $\mathrm{CO}_{2}$ flow rate at the three studied temperatures.

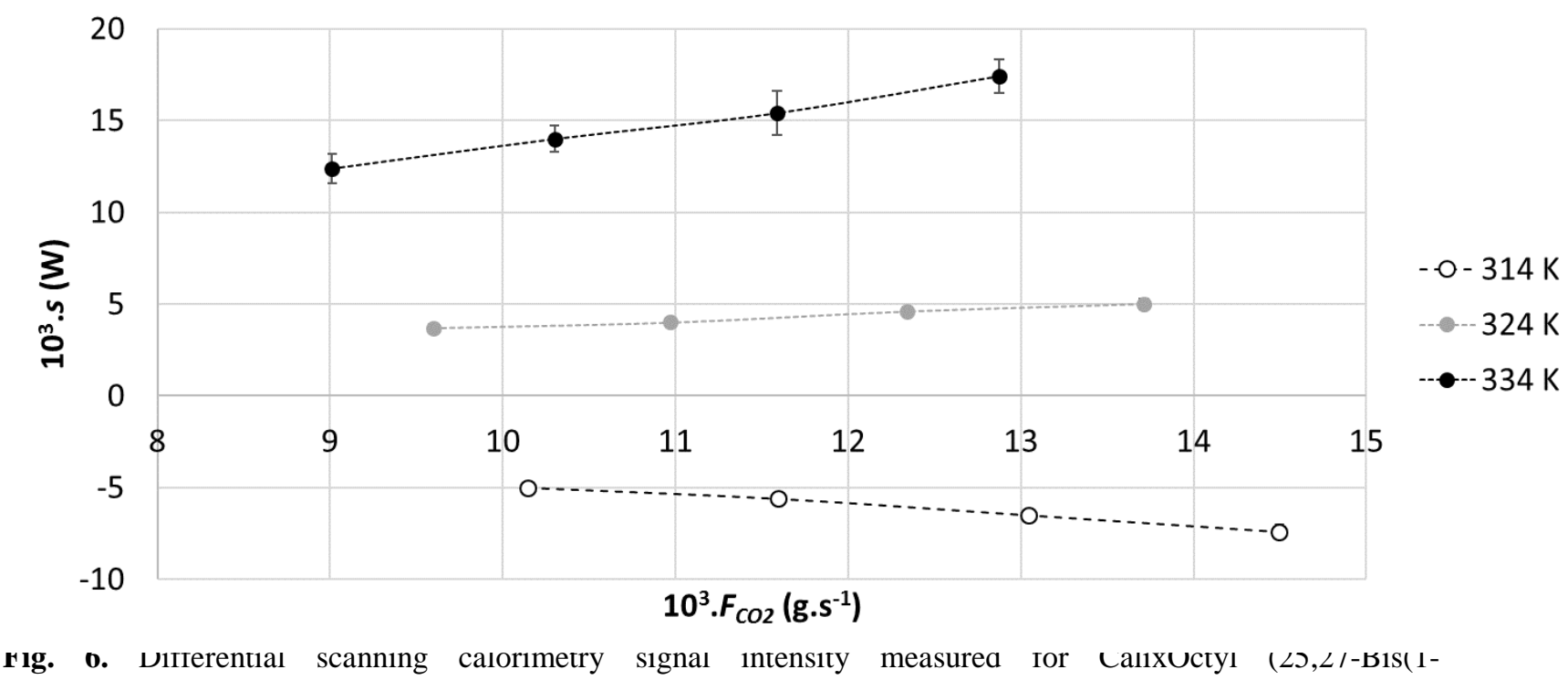


octyloxy)calix[4]arene-crown-6, 1,3-alternate) as a function of the $\mathrm{CO}_{2}$ flow rate at 314, 324 and $334 \mathrm{~K}$ and 24.0 MPa.

Table 3 lists the correlations obtained between the DSC signal and the $\mathrm{CO}_{2}$ flow rate at the three temperatures, along with the corresponding values of CalixOctyl's enthalpy of solution in $\mathrm{CO}_{2}$, calculated using Eq. 9 and the solubility data in Table 2.

\section{Table 3.}

Correlation between the differential scanning calorimetry signal $(s)$ and the $\mathrm{CO}_{2}$ flow rate $\left(\mathrm{F}_{\mathrm{CO}_{2}}\right)$ at $24 \mathrm{MPA}$ and three different temperatures, and the corresponding solution enthalpies of CalixOctyl (25,27-Bis(1octyloxy)calix[4]arene-crown-6, 1,3-alternate) in supercritical $\mathrm{CO}_{2}$ calculated using Eq. 9 .

$\mathrm{T}(\mathrm{K}) \quad \mathrm{s}(\mathrm{W}) \quad \Delta H_{\text {sol }}\left(\mathrm{kJ} . \mathrm{mol}^{-1}\right)$

$\begin{array}{ccc}314 & -0.498 \times F_{\mathrm{CO}_{2}}\left(R^{2}=\right. & -639.2 \\ & 0.980) & \\ 324 & 0.370 \times F_{\mathrm{CO}_{2}}\left(R^{2}=0.969\right) & 309.9 \\ 334 & 1.351 \times F_{\mathrm{CO}_{2}}\left(R^{2}=0.991\right) & 1395.4\end{array}$

The temperature dependence of CalixOctyl's enthalpy of solution is also linear at 24.0 MPa:

$\Delta H_{\text {sol }}(24.0 \mathrm{MPa}, T)=101.2 \times T+32421.9 \mathrm{~kJ} \cdot \mathrm{mol}^{-1}$

with $R^{2}=0.999$. As $\Delta H_{\text {sol }}$ is equal to zero at the crossover pressure (see Appendix, 21.4 $\mathrm{MPa}$ in this case), if one assumes that its variation with pressure is linear (following Stassi and Schiraldi [40]), the enthalpy of solution at a fixed temperature for any given pressure can be obtained from $\Delta H_{\text {sol }}(24.0 \mathrm{MPa})$ using Eq. (11):

$\Delta H_{\text {sol }}(P)=\frac{\Delta H_{\text {sol }}(24.0 \mathrm{MPa})}{(24.0-21.4)} \times(P-21.4)$ 
Using the values of $\Delta H_{\text {sol }}(24.0 \mathrm{MPa})$ determined at 314,324 and $334 \mathrm{~K}$, the estimated pressure dependences of the solution enthalpy at these temperatures are:

$\Delta H_{\text {sol }}(P, 314 \mathrm{~K})=-245.8 \times P+5260.8 \mathrm{~kJ} \cdot \mathrm{mol}^{-1}$

$\Delta H_{\text {sol }}(P, 324 \mathrm{~K})=119.2 \times P-2550.4 \mathrm{~kJ} \cdot \mathrm{mol}^{-1}$

$\Delta H_{\text {sol }}(P, 334 \mathrm{~K})=536.7 \times P-11485.1 \mathrm{~kJ} \cdot \mathrm{mol}^{-1}$

This experimental method thus enables solution enthalpies of solid compounds to be determined in $\mathrm{SC}-\mathrm{CO}_{2}$ at any pressure and temperature.

As explained by Chrastil [46], the solution enthalpy of an organic solid in $\mathrm{SC}-\mathrm{CO}_{2}$ is the sum of its sublimation enthalpy and its solvation enthalpy therein: $\Delta H_{\text {sol }}=\Delta H_{s u b}+$ $\Delta H_{\text {solv }}$, with $\Delta H_{\text {sub }}>0$ and $\Delta H_{\text {solv }}<0$. At a fixed pressure of $24.0 \mathrm{MPa}$, the increase with temperature of CalixOctyl's enthalpy of solution (see Table 3) is expected because as the temperature increases, the density and thus the solvent power of $\mathrm{CO}_{2}$ decrease, leading to weaker solvation. On the other hand, the sublimation enthalpy is known to increase with temperature.

A pressure increase at fixed temperature has a more ambiguous effect on the solution enthalpy. At $314 \mathrm{~K}$, CalixOctyl's enthalpy of solution decreases as the pressure increases. This is probably because the density and thus the solvation power of $\mathrm{CO}_{2}$ increase (through increased coordination between $\mathrm{CO}_{2}$ and the solute). For the two other temperatures, a pressure increase leads to an increase in the solution enthalpy. Zhang et al. [47] reported the same behavior for the solution enthalpy of naphthalene in $\mathrm{SC}-\mathrm{CO}_{2}$. Using quantum chemistry calculations, these authors showed that the $\mathrm{CO}_{2}$ energy level decreases as the pressure increases. As a result, the heat released during the formation of the solvent-solute clusters decreases as the pressure increases, which explains the decrease in the solvation enthalpy and 
thus the increase in the solution enthalpy. Further investigations combining in situ analytical methods to characterize the presence (or not) of clusters in the $\mathrm{SC}-\mathrm{CO}_{2}$ phase (such as smallangle X-ray scattering and small-angle neutron scattering) and molecular simulations would be necessary to completely elucidate this solubilization mechanism.

\section{Conclusions}

We have determined the solubility of CalixOctyl in $\mathrm{SC}-\mathrm{CO}_{2}$. Although calixarenes are promising selective extractants of metals, there are very few studies devoted to the solubilities of calixarenes in $\mathrm{SC}_{-} \mathrm{CO}_{2}$ in the literature. Information on the solubility of CalixOctyl in SC$\mathrm{CO}_{2}$ will also help to optimize existing processes. The solubility of CalixOctyl in $\mathrm{SC}-\mathrm{CO}_{2}$ varies from $(0.20 \pm 0.02) \cdot 10^{-6} \mathrm{~mol} . \mathrm{mol}^{-1}$ at $334 \mathrm{~K}$ and $10.4 \mathrm{MPa}$, to $(72.78 \pm 0.31) \cdot 10^{-6}$ mol.mol ${ }^{-1}$ at $324 \mathrm{~K}$ and $27.4 \mathrm{MPa}$, always increasing with pressure at fixed temperature. Although the CalixOctyl molecule combines the structures of a calixarene and of a crown ether, similar to the latter, its solubility is 100 times higher than that of simple calixarenes. However, the solubility curves of CalixOctyl have properties typical of both components, exhibiting a crossover pressure (as those of crown ethers do) and a maximum at an intermediate temperature of $324 \mathrm{~K}$ (as also observed for $p$-t-butylcalix[4]arene). Its good selectivity towards cesium [24] and far greater solubility in $\mathrm{SC}-\mathrm{CO}_{2}$ thus make CalixOctyl a more promising extractant than simple calixarenes.

An experimental setup based on differential scanning calorimetry was also developed in this study to measure the solution enthalpies of solid compounds in $\mathrm{SC}-\mathrm{CO}_{2}$. As expected, CalixOctyl's enthalpy of solution increases linearly with temperature at fixed pressure as the $\mathrm{CO}_{2}$ density and solvation power decrease. Likewise, the solvation weakens and the solution enthalpy increases for pressure increases at fixed temperatures of 324 and $334 \mathrm{~K}$. This is likely due to a decrease of the energy released by the formation of solvent-solute clusters. At 
$314 \mathrm{~K}$ however, the solution enthalpy decreases as the pressure $\left(\mathrm{CO}_{2}\right.$ density) is increased, probably because of stronger solvation.

In the context of future thermodynamic studies of metal extraction systems, the data obtained in this work could be incorporated in a global investigation of ternary metal extraction systems involving CalixOctyl, a cationic exchanger and $\mathrm{SC}-\mathrm{CO}_{2}$. A better understanding of the physicochemical properties of these complex systems would indeed facilitate the scaling up of experimental processes for industrial applications.

\section{Appendix}

At the crossover pressure $\left(P_{c o}\right)$, the molar solution enthalpy of CalixOctyl in $\mathrm{SC}-\mathrm{CO}_{2}$ can be written:

$\Delta H_{\text {sol }}\left(T, P_{\text {co }}\right)=H_{\text {Calixoctyl in } S C-C O 2}\left(T, P_{\text {co }}\right)-H_{\text {Calixoctyl }}\left(T, P_{\text {co }}\right)$

where $H_{\text {Calixoctyl in SC-CO2 }}$ is the molar enthalpy of CalixOctyl in $\mathrm{SC}-\mathrm{CO}_{2}$ and $H_{\text {Calixoctyl }}$ is the molar enthalpy of pure CalixOctyl.

The chemical potential of CalixOctyl in $\mathrm{SC}-\mathrm{CO}_{2}$ at $P_{c o}$ is given by Eq. (A.2):

$\mu_{\text {Calixoctyl in } S C-\mathrm{CO} 2}\left(T, P_{\text {co }}\right)=$

$\mu_{\text {CalixOctyl }}\left(T, P_{\text {co }}\right)+R \times T \times \operatorname{Ln}\left(a_{\text {CalixOctyl in } S C-C O 2}\left(T, P_{\text {co }}\right)\right)$

in which $a_{\text {CalixOctyl in } S C-C O 2}$ is the activity of CalixOctyl in $\mathrm{SC}_{-} \mathrm{CO}_{2}$. Eq. (A.2) can be rewritten in terms of $\gamma_{\text {CalixOctyl in } S C-C O 2}$, and $y$, respectively the activity coefficient and solubility of CalixOctyl in $\mathrm{SC}-\mathrm{CO}_{2}$, 
$\mu_{\text {CalixOctyl in } S C-\mathrm{CO} 2}\left(T, P_{\text {co }}\right)=$

$\mu_{\text {Calixoctyl }}\left(T, P_{\text {co }}\right)+R \times T \times \operatorname{Ln}\left(\gamma_{\text {CalixOctyl in SC-CO2 }}\left(T, P_{\text {co }}\right)\right)+R \times T \times \operatorname{Ln}\left(y\left(T, P_{\text {co }}\right)\right)$

(A.3)

As the solubility of CalixOctyl in $\mathrm{SC}-\mathrm{CO}_{2}$ is low $\left(y<10^{-4} \mathrm{~mol} \cdot \mathrm{mol}^{-1}\right)$, one can assume that $\gamma_{\text {CalixOctyl in } S C-C O 2}\left(T, P_{C o}\right)=1$, hence:

$\frac{\mu_{\text {CalixOctylin } S C-C O 2}\left(T, P_{c o}\right)}{R \times T}=\frac{\mu_{\text {CalixOctyl }}\left(T, P_{c o}\right)}{R \times T}+\operatorname{Ln}\left(y\left(T, P_{c o}\right)\right)$

Differentiating with respect to temperature yields:

$\frac{1}{R} \frac{\partial\left(\frac{\mu_{\text {CalixOctylin } S C-C O 2}\left(T, P_{C o}\right)}{T}\right)}{\partial T}=\frac{1}{R} \frac{\partial\left(\frac{\mu_{\text {Calixoctyl }}\left(T, P_{c o}\right)}{T}\right)}{\partial T}+\frac{\partial L n\left(y\left(T, P_{c o}\right)\right)}{\partial T}$

As pointed out by Foster et al. [48], the mathematical criteria for the crossover pressure is $\frac{\partial \operatorname{Ln}\left(y\left(T, P_{c o}\right)\right)}{\partial T}=0$ so:

$\frac{\partial\left(\frac{{ }_{\text {CalixOctyl in } S C-C O 2}\left(T, P_{c o}\right)}{T}\right)}{\partial T}=\frac{\partial\left(\frac{\mu_{\text {CalixOctyl }}\left(T, P_{c o}\right)}{T}\right)}{\partial T}$

Using the Gibbs-Helmoltz equation $\left(\frac{\partial\left(\frac{\mu}{T}\right)}{\partial T}\right)_{P}=-\frac{H}{T^{2}}$, Eq. 6 becomes:

$H_{\text {CalixOctyl in } S C-C O 2}\left(T, P_{\text {co }}\right)=H_{\text {Calixoctyl }}\left(T, P_{\text {co }}\right)$

And finally, substituting Eq. (A.7) into Eq. (A.1) yields:

$$
\Delta H_{\text {sol }}\left(T, P_{c o}\right)=0
$$




\section{Acknowledgments}

The authors wish to acknowledge the ANR DEMETERRES project and AREVA for their financial support and Marine Cordray, Amélys Venditti and Pierre Venditti for their technical help.

\section{References}

[1] A. Baeyer, Ueber die verbindungen der aldehyde mit den phenolen, Berichte der deutschen chemischen Gesellschaft 5 (1872) 280-282.

[2] C.D. Gutsche, Calixarenes: An Introduction ( $2^{\text {nd }}$ Edition), RSC Publishing, 2008.

[3] R. Perrin, R. Lamartine and M. Perrin, The potential industrial applications of calixarenes, Pure \& Appl. Chem. 65 (1993) 1549-1559.

[4] K. Seiffarth, M. Schulz, G. Goermar, J. Bachmann, Calix[n]arenes-new light stabilizers for polyolefins, Polym. Degrad. Stabil. 2 (1989) 73-80.

[5] H. Taniguchi, E. Nomura, Catalytic activity of an octopus-type calixarene on the formation of ethers, Chem. Lett. 17 (1988) 1773-1776.

[6] S.J. Harris, J. Guthrie, M.G. MacManus, Encapsulating compositions, Eur. Patent EP0262910A2, 1988.

[7] S.J. Harris, M.G. MacManus, Functionalised oxacalixarenes, their preparation and use in instant adhesive compositions, Eur. Patent EP0279521A1, 1988.

[8] R. Ben Chaâbane, M. Gamoudi, G. Guillaud, C. Jouve, F. Gaillard, R. Lamartine, Elaboration and characterization of thin calixarene films, Synthetic Met. 66 (1994) 49-54.

[9] M. Erdoğan, R. Çapan, F. Davis, Swelling behaviour of calixarene film exposed to various organic vapours by surface plasmon resonance technique, Sensor Actuat. B-Chem. 145 (2010) $66-70$. 
[10] T. Arimura, T. Nagasaki, S. Shinkai, T. Matsuda, Host-guest properties of new watersoluble calixarenes derived from p-(chloromethyl) calixarenes, J. Org. Chem. 3 (1989) 37663768.

[11] B. Kneafsey, J.M. Rooney, S.J. Harris, Polymerization catalysts and polymerization process using such catalysts, US Patent US4912183A, 1990.

[12] M. Atanassova, V. Kurteva, Synergism as a phenomenon in solvent extraction of 4felements with calixarenes, RSC Adv. 6 (2016) 11303-11324.

[13] B. Mokhtari, K. Pourabdollah, Binding abilities and extractive applications of nanobaskets of calixarenes, Asian J. Chem. 23 (2011) 4717-4734.

[14] B. Mokhtari, K. Pourabdollah, N. Dallali, A review of calixarene applications in nuclear industries, J. Radioanal. Nucl. Chem. 287 (2011) 921-934.

[15] R. Ludwig, Calixarenes in analytical and separation chemistry, Fresenius J. Anal. Chem. 367 (2000) 103-128.

[16] M. Tabakci, B. Tabakci, M. Yilmaz, Design and synthesis of new chiral calix[4]arenes as liquid phase extraction agents for $\alpha$-amino acid methylesters and chiral $\alpha$-amines, J. Incl. Phenom. Macrocycl. Chem. 53 (2005) 51-56.

[17] V. Torgov, G. Kostin, V. Mashukov, T. Korda, A. Drapailo, V. Kalchenko, Complexation and reduction of gold (III) during extraction from $\mathrm{HCl}$ by calix[4,6]arenes upper-Rim functionalized with alkyl- or tolylthiamethyl groups, Solv. Extract. Ion Exch. 23 (2005) 171-187.

[18] G.A. Kostin, T.V. Us, T.M. Korda, V.G. Torgov, N.V. Kuratieva, S.I. Miroshnichenko, V.I. Kalchenko, Complexation and extraction of non-ferrous metals by calix[n]arene phosphine oxides, J. Incl. Phenom. Macrocycl. Chem. 68 (2010) 131-137.

[19] R. Ludwig, N.T.K. Dzung, Solvent extraction of Tc(VII) by calixarenes bearing pyridino groups, J. Nucl. Radiochem. Sci. 6 (2005) 227-231. 
[20] F. Sansone, M. Fontanella, A. Casnati, R. Ungaro, V. Böhmer, M. Saadioui, K. Liger, JF. Dozol, CMPO-substituted calix[6]- and calix[8]arene extractants for the separation of $\mathrm{An}^{3+} / \mathrm{Ln}^{3+}$ from radioactive waste, Tetrahedron 62 (2006) 6749-6753.

[21] A. Leydier, D. Lecerclé, S. Pellet-Rostaing, A. Favre-Reguillon, F. Taran, M. Lemaire, Sequestering agents for uranyl chelation: new calixarene ligands, Tetrahedron 64 (2008) $11319-11324$.

[22] C. Park, S. Chun, R.A. Bartsch, Effect of conformation on metal ion extraction by calix[4]arene dicarboxylic acids, J. Incl. Phenom. Macrocycl. Chem. 66 (2010) 95-105.

[23] K. Ohto, H. Ishibashi, H. Kawakita, K. Inoue, T. Oshima, Allosteric coextraction of sodium and metal ions with calix[4]arene derivatives 1: role of the first-extracted sodium ion as an allosteric trigger for self-coextraction of sodium ions with calix[4]arene tetracarboxylic acid, J. Incl. Phenom. Macrocycl. Chem. 65 (2009) 111-120.

[24] J-F. Dozol, H. Rouquette, R. Ungaro, A. Casnati, Calix[4]arènes-couronnes, leur procédé de préparation et leur utilisation pour l'extraction sélective du césium et des actinides, Fr. Patent FR2704225A1, 1993.

[25] A. Casnati, A. Pochini, R. Ungaro, F. Ugozzoli, F. Arnaud, S. Fanni, M-J. Schwing, R.J.M. Egberink, F. de Jong, D.N. Reinhoudt, Synthesis, complexation, and membrane transport studies of 1,3-alternate calix[4]arene-crown-6 conformers: a new class of cesium selective ionophores, J. Am. Chem. Soc. 117 (1995) 2767-2777.

[26] H. Luo, S. Dai, P.V. Bonnesen, A.C. Buchanan III, J.D. Holbrey, N.J. Bridges, R.D. Rogers, Extraction of cesium ions from aqueous solutions using calix[4]arene-bis(tertoctylbenzo-crown-6) in ionic liquids, Anal. Chem. 76 (2004) 3078-3083.

[27] R. Pierce, T. Peters, T. Caldwell, M. Crowder, S. Fink, Performance testing of the nextgeneration CSSX solvent with actual SRS tank waste, Sep. Sci. Technol. 47 (2012) 20882097. 
[28] J. Rais, S. Tachimori, E. Yoo, J. Alexová, M. Bubeníková, Extraction of radioactive Cs and $\mathrm{Sr}$ from nitric acid solutions with 25,27-bis(1-octyloxy)calix[4]-26,28-crown-6 and dicyclohexyl-18-crown-6: effect of nature of the organic solvent, Sep. Sci. Technol. 50 (2015) 1202-1212.

[29] B.A. Moyer, J.F. Birdwell Jr., P.V. Bonnesen, S.H. Bruffey, L.H. Delmau, N.C. Duncan, D.D. Ensor, T.G. Hill, D.L. Lee, A. Rajbanshi, B.D. Roach, P.L. Szczygiel, F.V. Sloop Jr., E.L. Stoner, N.J. Williams, Next generation solvent development for caustic-side solvent extraction of cesium, ORNL/TM-2014/22 report, 2014.

[30] T. Sun, W. Duan, J. Wang, J. Wang, J. Chen, Hydraulic and mass-transfer performance of a 20-mm-diameter annular centrifugal contactor for the solvent extraction of cesium by bis(2-propyloxy)calix[4]-crown-6 in n-octanol, Solv. Extr. Ion Exch. 33 (2015) 75-90.

[31] J. Wang, J. Chen, J. Shan, Verification of the calixcrown process for partitioning cesium from high-level liquid waste (HLLW), Solv. Extr. Ion Exch. 33 (2015) 249-263.

[32] H. Zhou, M.A. Surowiec, R.A. Bartsch, T.J. Haverlock, B.A. Moyer, L.H. Delmau, Highly lipophilic, mono-ionizable calix[4]arenebenzocrown-6 extractants for removal of radiocesium from nuclear wastes, Solv. Extr. Ion Exch. 31 (2013) 697-714.

[33] P.K. Mohapatra, S.A. Ansari, A. Sarkar, A. Bhattacharyya, V.K. Manchanda, Evaluation of calix-crown ionophores for selective separation of radio-cesium from acidic nuclear waste solution, Anal. Chim. Acta 571 (2006) 308-314.

[34] A. Leybros, A. Grandjean, N. Segond, M. Messalier, O. Boutin, Cesium removal from contaminated sand by supercritical $\mathrm{CO}_{2}$ extraction, J. Environ. Chem. Eng. 4 (2016) 10761080.

[35] A.S. Kanekar, P.N. Pathak, P.K. Mohapatra, Online recovery of radiocesium from soil, cellulose and plant samples by supercritical fluid extraction employing crown ethers and calix-crown derivatives as extractants, J. Radioanal. Nucl. Chem. 300 (2014) 1281-1289. 
[36] B.F. Graham, A.F. Lagalante, T.J. Bruno, J.M. Harrowfield, R.D. Trengove, Solubility of $p$-t-butylcalixarenes in supercritical carbon dioxide: a comparison of static and dynamic measurement techniques, Fluid Phase Equilib. 150-151 (1998) 829-838.

[37] W. Cross Jr., A. Akgerman, C. Erkey, Determination of metal-chelate complex solubilities in supercritical carbon dioxide, Ind. Eng. Chem. Res. 35 (1996) 765-1770.

[38] H-S. Byun, M-Y. Choi, J-S. Lim, High-pressure phase behavior and modeling of binary mixtures for alkyl acetate in supercritical carbon dioxide, J. Supercrit. Fluids 37 (2006) 323332.

[39] Thermophysical Properties of Fluid Systems, National Institute of Standards and Technology, Available online: http://webbook.nist.gov/chemistry/fluid/ (accessed March 2016).

[40] A. Stassi, A. Schiraldi, Solubility of vegetable cuticular waxes in supercritical $\mathrm{CO}_{2}$ : isothermal calorimetry investigations, Thermochim. Acta 246 (1994) 417-425.

[41] M. Riva, A. Schiraldi, Kinetic parameterization of transitions and reactions in food systems from isothermal and non-isothermal DSC traces, Thermochim. Acta 220 (1993) 117130.

[42] M. Shamispur, Y. Yamini, J. Hasan, Solubility of large crown ethers in supercritical carbon dioxide, Fluid Phase Equilib. 186 (2001) 39-46.

[43] R.B. Gupta, J.J. Shim, Solubility in supercritical carbon dioxide, first ed., CRC Press Taylor \& Francis Group, Boca Raton, 2006.

[44] T. Sarbu, T.J. Styranec, E.J. Beckman, Non-fluorous polymers with very high solubility in supercritical $\mathrm{CO}_{2}$ down to low pressures, Nature 405 (2000) 165-168.

[45] S. Kilic, S. Michalik, Y. Wang, J.K. Johnson, R.M. Enick, E.J. Beckman, Effect of grafted Lewis base groups on the phase behavior of model poly(dimethyl siloxanes) in $\mathrm{CO}_{2}$, Ind. Eng. Chem. Res. 42 (2003) 6415-6424. 
[46] J. Chrastil, Solubility of solids and liquids in supercritical gases, J. Phys. Chem. 86 (1982) 3016-3021.

[47] X. Zhang, B. Han, J. Zhang, H. Li, J. He, H. Yan, Direct measurements of the enthalpy of solution of solid solute in supercritical fluids: study on the $\mathrm{CO}_{2}$-naphthalene system, Chem. Eur. J. 7 (2001) 4237-4242.

[48] N.R. Foster, G.S. Gurdial, J.S.L. Yun, K.K. Liong, K.D. Tilly, S.S.T. Ting, H. Singh, J.H. Lee, Significance of the crossover pressure in solid-supercritical fluid phase equilibria, Ind. Eng. Chem. Res. 30 (1991) 1955-1964. 